\title{
PENINGKATAN KEMAMPUAN GURU PAH DALAM MEMANFAATKAN LINGKUNGAN SEKOLAH SEBAGAI SUMBER BELAJAR MELALUI DISKUSI KELOMPOK KERJA GURU (KKG) DI GUGUS KAWAN KECAMATAN BANGLI TAHUN 2018
}

\author{
Oleh : \\ I Nyoman Wiranata \\ Kemenag Kabupaten Bangli \\ Wiranata1965@gmail.com
}

Diterima 11 Oktober 2018, direvisi 6 Pebruari 2019, diterbitkan 29 Maret 2019

\begin{abstract}
One of the government agenda is to improve the quality of national education curriculum. The Centralistic of National curriculum system implementation has produced cognitive behaviors of students who are less flexible. According to the current 2013 curriculum, it requires new strategies, especially in learning activities. The learning approach which was previously dominated by the role of the teacher (teacher centered) was updated with a studentcentered learning system. One of this learning strategies are using the Pakem approach. By utilizing the school environment as a learning resource, the implementation standard of learning, the students will be able to develop creativity, motivation and participation in learning process. Furthermore, based on the results of the observation as a supervisors of Hinduism education, (PAH) teachers in the Cluster of Bangli district, are very rare and never used the school environment as a source of learning. The study was conducted to utilize the school environment as a learning resource and to find out the weaknesses and strengths of the (PAH) Teacher Working Group (KKG) discussion in improving teachers' ability. This study was a School Action Research which carried out in two cycles, where each cycle was carried in three meetings. The subjects of this study were (PAH) teachers in Cluster which 8 number of people. The data was collected by using the observation format, learning scenario assessment instruments and assessment instruments for learning implementation. Furthermore, the collected data is analyzed by using descriptive analysis. Based on the result of this study it can be found that, in the first cycle the average value obtained from the teacher's attitude to discuss the discussion was 79.38, while in the second cycle the average value obtained was 84.88. The average value obtained from the assessment of learning scenario in the first cycle is 78.75, while in the second cycle the average value obtained 82.50. The average value obtained from the assessment of learning implementation in the first cycle is 78.33, while in the second cycle the average value obtained 82.08. By looking at the average value obtained from the results of the analysis, it can be concluded that, from cycle I to cycle II, an increase in the average value obtained from each component is observed and assessed, which means that the guidance through the teacher working group discussion approach can improve the ability of teachers in using the school environment. Based on the result mentioned above, it is suggested to (PAH) teachers in Bangli Districts to optimize the use of the school environment as a learning resource by increasing the variety of learning methods in the preparation of learning scenarios and in the implementation of learning.
\end{abstract}

Keywords : environment, learning resources, $K K G$ 


\section{PENDAhuluan}

Salah satu agenda pemerintah untuk meningkatkan kualitas pendidikan nasional adalah penyempurnaan kurikulum. Pelaksanaan sistem kurikulum nasional yang sentralistik telah menghasilkan prilaku kognitif siswa yang kurang fleksibel, kurang terbuka terhadap pendapat yang divergen. Siswa merasa lebih aman dan cendrung terikat pada apa yang telah ada, pikiran mereka kurang berkembang dan cendrung kurang suka pada sesuatu yang baru. Praktikpraktik pendidikan yang dikembangkan kelihatannya lebih ditekankan pada pemikiran reproduktif, menekankan pada hafalan dan mencari satu jawaban benar terhadap soalsoal yang diberikan. Akhirnya kompetensi belajar kurang berkembang secara optimal.

Untuk itu sesuai Kurikulum 2013 yang berlaku sekarang ini, memerlukan strategi baru terutama dalam kegiatan pembelajaran. Pendekatan pembelajaran yang sebelumnya lebih banyak didominasi oleh peran guru (teacher centered) diperbaharui dengan sistem pembelajaran yang berpusat pada siswa (student centered). Dalam implementasi Kurikulum 2013 guru harus mampu memilih dan menerapkan model, motode atau setrategi pembelajaran yang sesuai dengan karakteristik materi sehingga mampu mengembangkan daya nalar siswa secara optimal.Dengan demikian dalam pembelajaran guru tidak hanya terpaku dengan pembelajaran di dalam kelas, melainkan guru harus mampu melaksanakan pembelajaran dengan motode yang variatif.

Disamping itu sesuai dengan pendekatan PAKEM (Pembelajaran Aktif Kreatif dan Menyenangkan), guru harus mampu menghadapkan siswa dengan dunia nyata sesuai dengan yang dialaminya sehari-hari.

Salah satu strategi pembelajaran yang sesuai dengan pendekatan Pakem yang memungkinkan bisa mengembangkan kreativiats, motivasi dan partisipasi siswa dalam pembelajaran adalah dengan memanfaatkan lingkungan sekolah sebagai sumber belajar. Hal ini juga sesuai dengan salah satu pilar dari pendekatan contekstual yaitu masyarakat belajar (learning commonity). Untuk mencapai tujuan tersebut, salah satu cara belajar yang disarankan dalam Kurikulum 2013 sebagai upaya mendekatkan aktivitas belajar siswa pada berbagai fakta kehidupan sehari-hari di sekitar lingkungan siswa. Memanfaatkan lingkungan sekolah sebagai sumber belajar menjadi alternatif setrategi pembelajaran untuk memberikan kedekatan teoritis dan praktis bagi pengembangan hasil belajar siswa secara optimal. Ekowati (2001) mengatakan, memanfaatkan lingkungan sekolah sebagai sumber belajar merupakan bentuk pembelajaran yang berpihak pada pembelajaran melalui penggalian dan penemuan (experiencing) serta keterkaitan (relating) antara materi pelajaran dengan konteks pengalaman kehidupan nyata melalui kegiatan proyek. Pada pembelajaran dengan strategi ini guru bertindak sebagai pelatih metakognitif yaitu membantu pebelajar dalam menemukan materi belajar, mengintegrasikan pengetahuan dan ketrampilan dalam pembuatan laporan dan dalam penampilan hasil dalam bentuk presentasi.

Dari hasil pantauan peneliti selaku pengawas Pendidikan Agama Hindu, selama ini para guru masih sangat jarang memanfaatkan lingkungan sekolah sebagai sumber belajar. Lingkungan sekolah tidak lebih hanya digunakan sebagai tempat bermain-main siswa

Pada saat istirahat. Kalau tidak jam istirahat, guru lebih sering memilih mengkarantina siswa di dalam kelas, walaupun misalnya siswa sudah merasa sangat jenuh berada di dalam kelas.

Seperti observasi awal yang dilakukan di sekolah segugus Kawan,hal ini terlihat jelas dari rumusan RPP yang telah disusun oleh guru-guru di sekolah tersebut tidak ada memanfaatkan lingkungan sekolah sebagai sumber belajar.Padahal materi Pendidikan Agama Hindu sangat erat kaitannya dengan budaya dan adat istiadat. Guru lebih sering menyajikan pelajaran di dalam kelas walaupun materi yang disajikan berkaitan dengan lingkungan sekolah/budaya yang ada 
di sekitar sekolah. Dari wawancara yang dilakukan peneliti, sebagian besar guru mengaku enggan mengajak siswa belajar di luar kelas, karena alasan susah mengawasi. Selain itu ada guru yang menyampaikan bahwa mereka tidak bisa dan tidak tahu dalam memanfaatkan lingkungan sekolah sebagai sumber belajar.

Untuk mengatasi hal itu perlu adanya diskusi kelompok diantara para guru Pendidikan Agama Hindu di Gugus Kawan dalam bentuk KKG PAH untuk mendiskusikan masalah pemanfaatan lingkungan sekolah sebagai sumber belajar.

Dalam kegiatan diskusi tersebut para guru bisa membagi pengalaman dalam pemanfaatan lingkungan sekolah sebagai sumber belajar untuk mencapai hasil belajar yang optimal khusunya dalam pelajaran Agama Hindu. Penelitian Nur Mohamad dalam Ekowati (2001) menunjukkan diskusi kolompok memiliki dampak yang amat positif bagi guru yang tingkat pengalamannya rendah maupun yang tingkat pengalamannya tinggi.

Bagi guru yang tingkat pengalamannya tinggi akan menjadi lebih matang dan bagi guru yang tingkat pengalamannya rendah akan menambah pengetahuan. Keunggulan diskusi kelompok melalui KKG PAH adalah keterlibatan guru bersifat holistic dan komprehensip dalam semua kegiatan. Dari segi lainnya guru dapat menukar pendapat, memberi saran, tanggapan dan berbagai reaksi sosial dengan teman seprofesi sebagai peluang bagi mereka untuk meningkatkan kemampuan dan pengalaman.

Berdasarkan latar belakang tersebut di atas, serta hasil pengamatan peneliti melalui supervisi,maka dapat diidentifikasi masalahnya sebagai berikut:

1. Pendekatan pembelajaran $\mathrm{PAH}$ lebih banyak didominasi oleh peran guru, dan guru satu-satunya sumber belajar,selain buku paket.

2. Pembelajaran PAH yang dikembangkan di kelas - kelas kelihatannya lebih ditekankan pada pemikiran reproduktif, menekankan pada hafalan dan mencari satu jawaban benar terhadap soal-soal yang diberikan.

3. Dalam kegiatan pembelajaran PAH guru belum mampu menerapkan model, motode atau strategi pembelajaran yang sesuai dengan karakteristik materi yang diajarkan sehingga kurang mengembangkan daya nalar siswa secara optimal.

4. Dalam proses pembelajaran PAH guru sangat jarang memanfaatkan lingkungan sekolah sebagai sumber belajar,walaupun materi pelajaran ada kaitannya dengan lingkungan sekolah.

5. Kegiatan Kelompok Kerja Guru (KKG) PAH belum dimanfaatkan dan dilaksanakan secara optimal.

Berdasarkan identifikasi masalah diatas,maka dalam penelitian tindakan sekolah ini difokuskan pada penelitian masalah memanfaatkan lingkungan sekolah sebagai sumber belajar yang dapat dirumuskan sebagai berikut :

1. Apakah kemampuan guru dalam memanfaatkan lingkungan sekolah sebagai sumber belajar dapat ditingkatkan melalui diskusi Kelompok Kerja Guru PAH di Gugus Kawan?

2. Apakah kelemahan dan kelebihan pelaksanaan diskusi Kelompok Kerja Guru (KKG) PAH terhadap peningkatan kemampuan guru dalam memanfaatkan lingkungan sekolah sebagai sumber belajar di Gugus Kawan?

Berdasarkan pada rumusan masalah di atas, dapat ditentukan hipotesis tindakan dalam penelitian tindakan sekolah ini adalah : Diskusi Kelompok Kerja Guru (KKG) PAH, dapat meningkatkan kemampuan guru dalam memanfaatkan lingkungan sekolah sebagai sumber belajar di Gugus Kawan Kecamatan Bangli.

Berdasarkan rumusan masalah di atas, maka tujuan dari dilaksanakan penelitian tindakan sekolah ini adalah:

a. Untuk meningkatkan kemampuan guru dalam memanfaatkan lingkungan sekolah sebagai sumber belajar melalui 
diskusi Kelompok Kerja Guru (KKG) PAH di Gugus Kawan.

b. Untuk mengetahui kelemahan dan kelebihan pelaksanaan diskusi Kelompok Kerja Guru (KKG) PAH terhadap peningkatan kemampuan guru dalam memanfaatkan lingkungan sekolah sebagai sumber belajar di Gugus Kawan Hasil Penelitian Tindakan Kelas ini diharapkan memberikan manfaat yang berarti bagi :

a. Guru, dapat menyempurnakan metode pembelajaran yang diterapkan di sekolah sehingga dapat meningkatkan kreativias, motivasi dan hasil belajar siswa.

b. Sekolah, dapat memberikan motivasi bagi guru-guru yang lain untuk menyempurnakan imetode dan setrategi pembelajaran yang diterapkan di sekolah dalam upaya menngkatkan hasil belajar siswa.

c. Pengawas Pendidikan Agama Hindu, dapat membantu dalam membimbing dan memantau guru dalam pelaksanaan tugasnya sehingga dapat meningkatkan kompetensi dan profesionalisme guru.

d. Bagi Kementrian Agama atau instansi terkait sebagai bahan masukan terhadap pengambil kebijakan/keputusan dalam upaya meningkatkan kompetensi dan profesionalisme guru.

Pemanfaatan Lingkungan Sekolah sebagai Sumber Belajar, Salah satu alternatif metode pembelajaran yang sesuai dengan pendekatan Pembelajaran Aktif Kreatif dan Menyenangkan (PAKEM) adalah pembelajaran dengan memanfaatkan lingkungan sekolah sebagai sumber belajar. Lingkungan merupakan kesatuan ruang dengan semua benda dan keadaan mahluk hidup termasuk di dalamnya manusia dan prilakunya serta mahluk hidup lainnya. Lingkungan sebagai sumber belajar dapat dimaknai sebagai segala sesuatu yang ada disekitar atau di sekeliling anak (mahluk hidup lain, benda mati, dan budaya manusia) yang dapat dimanfaatkan untuk menunjang kegiatan belajar mengajar.
Sumber belajar masyarakat dapat digunakan untuk kepentingan proses pembelajaran sains, ilmu sosial dan yang lainnya, salah satunya melalui survei wilayah. Melalui survei wilayah siswa akan menemukan sumber belajar di masyarakat sehingga mampu menumbuhkan motivasi untuk memperkaya nilai-nilai hasil belajar guna dapat meningkatkan pemahaman dan peningkatan materi pelajaran. (Sarman, 2005 :3).

Nilai-nilai kegunaan sumber belajar masyarakat adalah : (1) menghubungkan kurikulum dengan kegiatan-kegiatan masyarakat akan mengembangkan kesadaran dan kepekaan terhadap masalah sosial; (2) menggunakan minat-minat pribadi peserta didik akan menyebabkan belajar lebih bermakna baginya; (3) mempelajari kondisikondisi masyarakat merupakan latihan berpikir ilmiah (scientif methode); (4) mempelajari masyarakat akan memperkuat dan memperkaya kurikulum melalui pelaksanaan praktis didalam situasi sesungguhnya; (5) peserta didik memperoleh pengalaman langsung yang kongkrit, realistis dan verbalisme. (Douglas dan Mill dalam Rusyan 2001 : 152)

\section{Metodologi Penelitian}

Penelitian Tindakan Sekolah ini berlokasi di Gugus Kawan Kecamatan Bangli yang merupakan gugus binaan dari peneliti. Penelitian ini ditujukan pada guru-guru Pendidikan Agama Hindu yang ada di sekolah lingkungan gugus Manikliu yang berjumlah 8 orang. Adapun alasan utamanya adalah dari hasil pengamatan dan informasi dari guru,bahwa hampir semua guru Agama Hindu jarang dan bahkan tidak pernah memanfaatkan lingkungan sekolah sebagai sumber belajar. Jenis tindakan dalam penelitian ini adalah berupa tindakan nyata yaitu membimbing guru memahami memanfaatkan lingkungan sekolah ,menyusun skenario pembelajaran dan pelaksanaan pembelajaran dengan memanfaatkan lingkungan sekolah sebagai 
sumber belajar melalui diskusi Kelompok Kerja Guru (KKG) PAH.

\section{Hasil Penelitian}

Penelitian tindakan sekolah ini dilaksanakan sesuai dengan perencanaan yang sudah disusun sebelumnya dengan tahapantahapan sebagai berikut :

1. Siklus I

Berdasarkan pengamatan awal di semua sekolah yang ada di gugus Kawan, semua guru Pendidikan Agama Hindu jarang dan bahkan tidak pernah memanfaatkan lingkungan sekolah sebagai sumber belajar. Hal ini terlihat jelas dari rumusan rencana pembelajaran yang telah disusun melalui hasil KKG PAH sebelumnya. Di samping itu hal ini disebabkan oleh kurangnya pemahaman dan kemampuan guru untuk memanfaatkan lingkungan sekolah sebagai sumber belajar.Selama ini guru lebih banyak menggunakan buku paket dan alat peraga yang dimiliki sekolah sebagai sumber belajar untuk melengkapi kegiatan pembelajaran di kelas. Demikian pula kegiatan pembelajaran di luar kelas sangat jarang dan bahkan tidak pernah dilakukan dengan alasan tidak cukup waktu, masalah keamanan dan keselamatan siswa.Hal ini sudah tentu kurang sesuai dengan pembelajaran yang menggunakan pendekatan pembelajaran aktif, kreatif, efektif dan menyenangkan(Pakem) yang harus dilaksanakan dalam penterapan kurikulum 2013. Kegiatan dalam siklus I ini, diawali dengan kegiatan diskusi kelompok kerja guru (KKG) PAH tentang permasalahan yang dihadapi dalam pemanfaatan lingkungan sekolah sebagai sumber belajar, dilanjutkan dengan informasi tentang manfaat lingkungan sekolah sebagai sumber belajar bagi siswa dan implementasinya dalam proses belajar mengajar. Saat guru berdiskusi dalam kelompok kerja guru (KKG)PAH pada siklus I, peneliti mengadakan observasi tentang sikap guru dalam berdiskusi yang hasilnya sebagai berikut :

Tabel. 4.1.1. Data Hasil Observasi

\begin{tabular}{|c|c|c|c|c|c|c|c|}
\hline \multirow{3}{*}{ No } & \multirow{3}{*}{ Nama Guru } & \multicolumn{4}{|c|}{ Aspek yang diobservasi } & \multirow{3}{*}{$\begin{array}{l}\text { Jumlah } \\
\text { Skor } \\
\text { Mak. } \\
100\end{array}$} & \multirow{3}{*}{$\begin{array}{c}\text { Kat } \\
\text { a } \\
\text { Gor } \\
\text { i }\end{array}$} \\
\hline & & \multirow{2}{*}{$\begin{array}{c}\begin{array}{c}\text { Kerjasa } \\
\text { ma }\end{array} \\
(1-10)\end{array}$} & \multirow{2}{*}{\begin{tabular}{|c|} 
Aktivitas \\
$(1-$ \\
$40)$
\end{tabular}} & \multirow{2}{*}{\begin{tabular}{|l|} 
Perhatian \\
$(1-20)$
\end{tabular}} & \multirow{2}{*}{\begin{tabular}{|c|}
$\begin{array}{c}\text { Present } \\
\text { asi }\end{array}$ \\
$(1-$ \\
$30)$
\end{tabular}} & & \\
\hline & & & & & & & \\
\hline 1 & Ni Nyoman Sidri & 8 & 30 & 15 & 27 & 80 & B \\
\hline 2 & I Wayan Pageh & 8 & 30 & 16 & 26 & 80 & B \\
\hline 3 & A.A.A. Made Suryani & 8 & 30 & 15 & 27 & 80 & $\mathrm{~B}$ \\
\hline 4 & Ni Made Adi Adnyani & 8 & 30 & 15 & 27 & 80 & $B$ \\
\hline 5 & Ni Putu Ratningsih & 8 & 31 & 16 & 26 & 81 & B \\
\hline 6 & I Nengah Nurit & 8 & 33 & 16 & 22 & 79 & C \\
\hline 7 & I Komang Budiana & 8 & 29 & 18 & 23 & 78 & C \\
\hline 8 & Ni Wayan Seniati & 8 & 30 & 14 & 25 & 77 & C \\
\hline & Jumlah & 64 & 243 & 125 & 203 & 635 & \\
\hline & Rata-rata & 8.00 & 30.38 & 15.63 & 25.38 & $\begin{array}{c}79.3 \\
8\end{array}$ & C \\
\hline
\end{tabular}

Penilaian terhadap skenario pembelajaran dalam bentuk program perencanaan pelaksanaan pembelajaran (RPP)PAH yang disusun guru dalam siklus I,didapatkan hasil sebagai berikut : 
Tabel.4.1.2. Data Hasil Penilaian Skenario Pembelajaran

\begin{tabular}{|c|c|c|c|c|c|c|c|c|}
\hline \multirow{2}{*}{ No } & \multirow{2}{*}{ Nama Guru } & \multicolumn{4}{|c|}{ Aspek yang dinilai } & \multirow{2}{*}{$\begin{array}{c}\text { Jumlah } \\
\text { Skor }\end{array}$} & \multirow{2}{*}{$\begin{array}{c}\text { Jumlah } \\
\text { Nilai }\end{array}$} & \multirow{2}{*}{ Katagori } \\
\hline & & 1 & 2 & 3 & 4 & & & \\
\hline 1 & Ni Nyoman Sidri & 4 & 4 & 4 & 5 & 17 & 85 & B \\
\hline 2 & I Wayan Pageh & 5 & 4 & 4 & 3 & 16 & 80 & $\mathrm{~B}$ \\
\hline 3 & A.A.A.Made Suryani & 5 & 4 & 3 & 5 & 17 & 85 & B \\
\hline 4 & Ni Made Adi Adnyani & 4 & 4 & 4 & 5 & 17 & 85 & B \\
\hline 5 & Ni Putu Ratningsih & 4 & 4 & 3 & 4 & 15 & 75 & $\mathrm{C}$ \\
\hline 6 & I Nengah Nurit & 4 & 4 & 3 & 4 & 15 & 75 & $\mathrm{C}$ \\
\hline 7 & I Komang Budiana & 4 & 3 & 3 & 3 & 13 & 65 & $\mathrm{C}$ \\
\hline 8 & Ni Wayan Seniati & 5 & 4 & 3 & 4 & 16 & 80 & $\mathrm{~B}$ \\
\hline & Jumlah & 34 & 31 & 28 & 33 & 126 & 630 & \\
\hline & Rata-rata & 4.25 & 3.88 & 3.50 & 4.13 & 15.75 & 78.75 & $\mathrm{C}$ \\
\hline
\end{tabular}

Sedangkan penilaian implementasi pemanfaatan lingkungan sekolah sebagai sumber belajar dalam kegiatan pembelajaran di kelas pada siklus I didapatkan hasil sebagai berikut :

Tabel.4.1.3. Data Hasil Penilaian Pelaksanaan Pembelajaran

\begin{tabular}{|c|c|c|c|c|c|c|c|c|c|c|}
\hline \multirow{2}{*}{ No } & \multirow{2}{*}{ Nama Guru } & \multicolumn{6}{|c|}{ Aspek yang dinilai } & \multirow{2}{*}{$\begin{array}{l}\text { Jumlah } \\
\text { Skor }\end{array}$} & \multirow{2}{*}{$\begin{array}{c}\text { Jumlah } \\
\text { Nilai }\end{array}$} & \multirow{2}{*}{ Katagori } \\
\hline & & 1 & 2 & 3 & 4 & 5 & 6 & & & \\
\hline 1 & Ni Nyoman Sidri & 5 & 4 & 5 & 4 & 4 & 4 & 26 & 86.67 & B \\
\hline 2 & I Wayan Pageh & 4 & 3 & 4 & 4 & 3 & 4 & 22 & 73.33 & $\mathrm{C}$ \\
\hline 3 & A.A.A.Made Suryani & 5 & 4 & 4 & 4 & 5 & 5 & 27 & 90.00 & $\mathrm{~A}$ \\
\hline 4 & Ni Made Adi Adnyani & 4 & 3 & 4 & 4 & 3 & 4 & 22 & 73.33 & $\mathrm{C}$ \\
\hline 5 & Ni Putu Ratningsih & 4 & 3 & 4 & 3 & 4 & 3 & 21 & 70.00 & $\mathrm{C}$ \\
\hline 6 & I Nengah Nurit & 5 & 4 & 4 & 4 & 4 & 5 & 26 & 86.67 & $\mathrm{~B}$ \\
\hline 7 & I Komang Budiana & 4 & 3 & 3 & 4 & 3 & 3 & 20 & 66.66 & $\mathrm{C}$ \\
\hline 8 & Ni Wayan Seniati & 4 & 4 & 4 & 4 & 4 & 4 & 24 & 80.00 & $\mathrm{~B}$ \\
\hline & Jumlah & 34 & 28 & 32 & 32 & 30 & 32 & 188 & 626.67 & \\
\hline & Rata-rata & 4.25 & 3.5 & 4 & 4 & 3.75 & 4 & 23.5 & 78.33 & $\mathrm{C}$ \\
\hline
\end{tabular}

Data penelitian tindakan sekolah yang diperoleh dari hasil observasi sikap guru dalam kegiatan diskusi kelompok kerja guru tentang pemanfaatan lingkungan sekolah sebagai sumber belajar pada siklus I,hasilnya termasuk katagori "cukup" dengan rata-rata nilai 79,38. Hal ini menunjukkan bahwa guru dalam berdiskusi belum menampakkan kerjasama,aktivitas dan perhatian yang baik terhadap permasalahan pemanfaatan lingkungan sekolah sebagai sumber belajar ,sehingga diperlukan bimbingan yang lebih intensif.

Penilaian skenario pembelajaran yang berbentuk rencana pelaksanaan pembelajaran (RPP)PAH hasilnya termasuk katagori

Peningkatan Kemampuan Guru PAH Dalam Memanfaatkan Lingkungan Sekolah Sebagai ....... “cukup" dengan rata-rata nilai 78.75. Hal ini menunjukkan bahwa kemampuan guru dalam menyusun skenario pembelajaran dengan memanfaatkan lingkungan sekolah sebagai sumber belajar perlu peningkatan.

Penilaian implementasi pemanfaatan lingkungan sekolah sebagai sumber belajar dalam kegiatan pembelajaran di kelas,hasilnya termasuk katagori "cukup" dengan rata-rata nilai 78.33. Hal ini menunjukkan bahwa guru dalam mengimplementasikan pemanfaatan lingkungan sekolah sebagai sumber belajar melalui kegiatan pembelajaran di kelas belum optimal,sehingga perlu peningkatan. 
Dengan adanya hasil observasi dan penilaian pada kegiatan siklusI maka peneliti melakukan refleksi. Dari refleksi terhadap seluruh kegiatan pada siklus I, maka ditemukan beberapa hambatan yang mengakibatkan belum optimalnya kemampuan guru memanfaatkan lingkungan sekolah sebagai sumber belajar.

Adapun hambatan-hambatan tersebut,antara lain guru belum sepenuhnya memahami manfaat lingkungan sekolah sebagai sumber belajar, dan guru dalam memilih sumber belajar dan memilih strategi pembelajaran dengan memanfaatkan lingkungan sekolah belum sesuai dengan yang diharapkan. Hal ini terlihat dalam skenario pembelajaran guru pada: aspek 1. jenis sumber belajar dari lingkungan sekolah tidak tercantum, padahal materi pelajaran ada kaitannya dengan lingkungan sekolah;. aspek 2. Kesesuaian antara materi pelajaran dengan media dan setrategi pembelajaran masih kurang; aspek 4. Kesesuaian antara tujuan pembelajaran dengan sumber bahan,lebih banyak hanya mencantumkan buku paket sebagai satu-satunya sumber belajar.

Dari hasil refleksi pelaksanaan pembelajaran di kelas, hambatan-hambatan yang ditemukan adalah sebagai berikut : aspek 1.dalam kegiatan awal,guru tidak memberi informasi tujuan pembelajaran dan waktunya belum sesuai dengan perencanaan; aspek 2 . kegiatan inti, langkah - langkah pembelajaran masih didominasi guru dengan metode ceramah sehingga kurang sesuai dengan pembelajaran aktif,kreatif,efektip dan menyenangkan (Pakem);aspek 3. Kemampuan guru mengkaitkan materi pelajaran dengan lingkungan sekolah belum optimal; aspek 6 . Penutup pelajaran, guru kurang memberi penekanan tentang lingkungan sekolah. Hambatan-hambatan tersebut akan disempurnakan pada kegiatan siklus II.

2. Siklus II.

Pada siklus II, kegiatan yang dilaksanakan adalah mendiskusikan hambatan- hambatan yang dialami dalam menyusun skenario pembelajaran dan pelaksanaan pembelajaran di kelas pada siklus I melalui kegiatan kelompok kerja guru (KKG)PAH. Adapun secara rinci uraian kegiatannya sebagai berikut :

Dalam penyusunan skenario pembelajaran khususnya pada aspek 1, 2 dan 4 guru melakukan revisi, dipandu oleh guru yang sudah mampu,dengan bimbingan peneliti/pengawas. Dalam pelaksanaan pembelajaran di kelas,terkait dengan hambatan pada aspek 1. kegiatan awal, aspek 2. kegiatan inti, aspek 3. kemampuan guru mengkaitkan materi pelajaran dengan lingkungan sekolah ,dan aspek 6 . penutup pelajaran, maka guru mendiskusikan kembali hambatan tersebut dalam kelompok kerja guru (KKG)PAH dibimbing pengawas/peneliti. Sebelum pelaksanaan pembelajaran di kelas, terlebih dahulu dilakukan simulasi atau modeling dengan menggunakan anggota kelompok guru sebagai siswa.

Sebagaimana kegiatan peneliti pada siklus I, maka kegiatan pada siklus keduapun dilakukan observasi,evaluasi dan penilaian. Hasil observasi terhadap sikap guru dalam berdiskusi pada siklus II dapat disajikan sebagai berikut : 
Tabel. 4.2.1. Data Hasil Observasi

Hasil penilaian terhadap skenario pembelajaran dalam bentuk rencana pelaksanaan pembelajaran(RPP)PAH dapat disajikan sebagai berikut :

\begin{tabular}{|c|c|c|c|c|c|c|c|}
\hline \multirow{3}{*}{ No } & \multirow{3}{*}{ Nama Guru } & \multicolumn{4}{|c|}{ Aspek yang diobservasi } & \multirow{3}{*}{$\begin{array}{c}\text { Jumlah } \\
\text { Skor } \\
\text { Mak.100 }\end{array}$} & \multirow{3}{*}{$\begin{array}{l}\text { Kate- } \\
\text { gori }\end{array}$} \\
\hline & & $\begin{array}{c}\text { Kerjasa } \\
\text { ma }\end{array}$ & Aktivitas & Perhatian & Presentasi & & \\
\hline & & $(1-10)$ & $(1-40)$ & $(1-20)$ & $(1-30)$ & & \\
\hline 1 & Ni Nyoman Sidri & 8 & 35 & 15 & 28 & 86 & $\mathrm{~B}$ \\
\hline 2 & I Wayan Pageh & 8 & 33 & 16 & 26 & 83 & $\mathrm{~B}$ \\
\hline 3 & A.A.A. Made Suryani & 8 & 38 & 18 & 28 & 92 & A \\
\hline 4 & Ni Made Adi Adnyani & 8 & 35 & 15 & 27 & 85 & B \\
\hline 5 & Ni Putu Ratningsih & 8 & 32 & 16 & 26 & 82 & $\mathrm{~B}$ \\
\hline 6 & I Nengah Nurit & 8 & 33 & 16 & 26 & 83 & B \\
\hline 7 & I Komang Budiana & 8 & 36 & 15 & 27 & 86 & $\mathrm{~B}$ \\
\hline 8 & Ni Wayan Seniati & 8 & 34 & 14 & 26 & 82 & $\mathrm{~B}$ \\
\hline & Jumlah & 64 & 276 & 125 & 214 & 679 & \\
\hline & Rata-rata & 8.00 & 34.50 & 15.63 & 26.75 & 84.88 & B \\
\hline
\end{tabular}

Tabel.4.2.2. Data Hasil Penilaian Skenario Pembelajaran

\begin{tabular}{|c|c|c|c|c|c|c|c|c|}
\hline \multirow{2}{*}{ No } & \multirow{2}{*}{ Nama Guru } & \multicolumn{4}{|c|}{ Aspek yang dinilai } & \multirow{2}{*}{$\begin{array}{c}\text { Jumlah } \\
\text { Skor }\end{array}$} & \multirow{2}{*}{$\begin{array}{c}\text { Jumlah } \\
\text { Nilai }\end{array}$} & \multirow{2}{*}{ Kategori } \\
\hline & & 1 & 2 & 3 & 4 & & & \\
\hline 1 & Ni Nyoman Sidri & 4 & 4 & 4 & 5 & 17 & 85 & B \\
\hline 2 & I Wayan Pageh & 5 & 4 & 4 & 4 & 17 & 85 & B \\
\hline 3 & A.A.A. Made Suryani & 4 & 4 & 4 & 5 & 17 & 85 & B \\
\hline 4 & Ni Made Adi Adnyani & 4 & 4 & 4 & 5 & 17 & 85 & $\mathrm{~B}$ \\
\hline 5 & Ni Putu Ratningsih & 4 & 4 & 4 & 4 & 16 & 80 & $\mathrm{~B}$ \\
\hline 6 & I Nengah Nurit & 4 & 4 & 4 & 4 & 16 & 80 & B \\
\hline 7 & I Komang Budiana & 4 & 4 & 4 & 4 & 16 & 80 & $\mathrm{~B}$ \\
\hline 8 & Ni Wayan Seniati & 4 & 4 & 4 & 4 & 16 & 80 & $\mathrm{~B}$ \\
\hline \multicolumn{2}{|r|}{ Jumlah } & 35 & 32 & 30 & 35 & 132 & 660 & \\
\hline \multicolumn{2}{|r|}{ Rata-rata } & 4.38 & 4.00 & 3.75 & 4.38 & 16.50 & 82.50 & B \\
\hline
\end{tabular}

Hasil penilaian terhadap Pelaksanaan Pembelajaran dapat disajikan sebagai berikut:

Tabel.4.2.3. Data Hasil Penilaian Pelaksanaan Pembelajaran

\begin{tabular}{|c|c|c|c|c|c|c|c|c|c|c|}
\hline \multirow{2}{*}{ No } & \multirow{2}{*}{ Nama Guru } & \multicolumn{6}{|c|}{ Aspek yang dinilai } & \multirow{2}{*}{$\begin{array}{c}\text { Jumlah } \\
\text { Skor }\end{array}$} & \multirow{2}{*}{$\begin{array}{l}\text { Jumlah } \\
\text { Nilai }\end{array}$} & \multirow{2}{*}{ Kategori } \\
\hline & & 1 & 2 & 3 & 4 & 5 & 6 & & & \\
\hline 1 & Ni Nyoman Sidri & 5 & 4 & 5 & 4 & 4 & 4 & 26 & 86.67 & B \\
\hline 2 & I Wayan Pageh & 4 & 4 & 4 & 4 & 4 & 4 & 24 & 80.00 & $\mathrm{~B}$ \\
\hline 3 & $\begin{array}{l}\text { A.A.A. Made } \\
\text { Suryani }\end{array}$ & 5 & 4 & 4 & 5 & 4 & 5 & 27 & 90.00 & A \\
\hline
\end{tabular}




\begin{tabular}{|c|l|c|c|c|c|c|c|c|c|c|}
\hline 4 & $\begin{array}{l}\text { Ni Made Adi } \\
\text { Adnyani }\end{array}$ & 4 & 3 & 4 & 4 & 4 & 4 & 23 & 76.67 & C \\
\hline 5 & Ni Putu Ratningsih & 4 & 4 & 4 & 4 & 4 & 4 & 24 & 80.00 & B \\
\hline 6 & I Nengah Nurit & 5 & 4 & 4 & 4 & 4 & 5 & 26 & 86.67 & B \\
\hline 7 & I Komang Budiana & 4 & 4 & 4 & 4 & 4 & 4 & 24 & 73.33 & C \\
\hline 8 & Ni Wayan Seniati & 4 & 4 & 4 & 4 & 4 & 4 & 24 & 80.00 & B \\
\hline & Jumlah & 35 & 30 & 33 & 33 & 32 & 34 & 197 & 656.67 & \\
\hline & Rata-rata & 4.3 & 3.7 & 4.1 & 4.1 & 4.0 & & & & \\
& 8 & 5 & 3 & 3 & 0 & 4.25 & 24.63 & 82.08 & B \\
\hline
\end{tabular}

Data yang diperoleh dari observasi sikap guru pada siklus II, setelah dianalisis ada peningkatan kearah perbaikan yaitu berada pada katagori "baik", dengan rata-rata nilai 84.88. Sedangkan untuk penilaian skenario pembelajaran dan penilaian pelaksanaan pembelajaran,masing-masing juga ada peningkatan yang ke arah yang lebih baik yaitu: untuk skenario pembelajaran berada pada katagori "baik" dengan nilai ratarata 82.50 , dan untuk penilaian pelaksanaan pembelajaran di kelas berada pada katagori "baik" dengan nilai rata-rata 82.08. Dengan melihat hasil pada siklus II, maka refleksi terhadap hasil yang diperoleh peneliti pada siklus II ini adalah adanya peningkatan kemampuan guru memanfaatkan lingkungan sekolah sebagai sumber belajar. Hal ini dibuktikan dengan nilai rata-rata yang diperoleh dalam memprogramkan pembelajaran serta dalam implementasinya di kelas yang sudah menunjukkan adanya peningkatan kemampuan guru untuk memanfaatkan lingkungan sekolah sebagai sumber belajar yang lebih baik.Sedangkan dari jumlah guru ,75\% sudah mencapai kriteria yang ditetapkan.

Berdasarkan data tersebut di atas dapat diketahui, bahwa pada penelitian di gugus Kawan guru Pendidikan Agama Hindu jarang dan bahkan tidak pernah memanfaatkan lingkungan sekolah sebagai sumber belajar,hal ini disebabkan oleh kurangnya pemahaman dan kemampuan guru untuk memanfaatkan lingkungan sekolah sebagai sumber belajar. Setelah diberikan tindakan melalui siklus I, ada peningkatan kemampuan guru-guru di Gugus Kawan dalam memanfaatkan lingkungan sekolah sebagai sumber belajar. Dari 8 orang guru yang terlibat, 5 orang guru sudah mendapat skor dengan katagori "baik" sedangkan 3 orang dengan katagori "cukup".Oleh karena itu dilanjutkan dengan tindakan siklus II yang hasilnya secara umum ada peningkatan ke arah yang lebih baik yaitu $75 \%$ guru sudah mendapatkan katagori baik dengan skor ratarata 80 - 89.Hal ini sudah sesuai dengan kriteria keberhasilan yang ditetapkan. Secara rinci perolehan nilai rata-rata peningkatan kemampuan guru memanfaatkan lingkungan sekolah sebagai sumber belajar yaitu nilai rata-rata observasi hasil kegiatan diskusi 79,38 di siklus I menjadi 84,88 di siklus II ada peningkatan $5,5 \%$. kegiatan penyusunan skenario pembelajaran nilai rata-rata 78,75 di siklus I menjadi 82,50 di siklus II ada peningkatan $3,75 \%$, kegiatan pembelajaran atau dalam proses belajar mengajar nilai ratarata 78,33 di sklus I menjadi 82,08 di siklus II, ada peningkatan $3,75 \%$

\section{KESIMPULAN}

Berdasarkan hasil analisis dan pembahasan siklus I dan siklus II tersebut di atas, maka dapat disimpulkan bahwa:

1. Ada peningkatan kemampuan guru dalam memanfaatkan lingkungan sekolah sebagai sumber belajar melalui pendekatan diskusi kelompok kerja guru (KKG) PAH di Gugus Kawan Kecamatan Bangli.

2. Dengan memanfaatkan kelebihan diskusi dalam kelompok kerja guru(KKG)PAH, akan dapat memecahkan masalah yang dihadapi guru terutama yang berkaitan dengan pemanfaatan lingkungan sekolah sebagai sumber belajar dalam proses 
belajar mengajar di Gugus Kawan Kecamatan Bangli.
Sutrisno Hadi, 2000. Metodelogi Penelitian. Yogyakarta : Andi

\section{SARAN}

\section{disarankan :}

Dari simpulan tersebut di atas,

1. Kepada.guru-guru khususnya guru di Gugus Kawan, di dalam menyusun skenario pembelajaran agar memanfaatkan semaksimal mungkin lingkungan sekolah dan lingkungan siswa yang sesuai dengan materi pembelajaran sebagai sumber belajar,dan mengintensifkan diskusi KKG PAH dalam memecahkan masalah yang dihadapi.

2. Kepada pihak sekolah, agar selalu memberikan motivasi bagi guru-guru yang lain untuk menyempurnakan metode dan setrategi pembelajaran yang diterapkan di sekolah khususnya di Gugus Kawan Kecamatan Bangli

\section{DAFTAR PUSTAKA}

Badru Zaman, dkk. 2005. Media dan Sumber Belajar TK. Buku Materi Pokok PGTK 2304. Modul 1-9. Jakarta Universiats Terbuka.

Ekowati, Endang. 2001. Stategi Pembelajaran Kooperatif. Modul Pelatihan Guru Terintegrasi Berbasis Kompetensi. Jakarta : Depdiknas.

Kasianto, I Wayan 2004 Meningkatkan Prestasi Belajar Siswa dengan Pendekatan Diskusi Kelompok. Laporan Penelitian Kelas. Tidak dipublikasikan

Rusyan Tabrani. 2001. Pendekatan dalam Proses Belajar Mengajar. Bandung Remaja Rosdakarya.

Sarman, Samsuni S.Pd. 2005. Implementasi Pendekatan Works Based Learning pada Sumber Belajar Masyarakat dalam Pembelajaran PS-Ekonomi. Laporan Penelitian Tindakan Kelas. Banjarmasin. Tidak dipublikasikan. 